\title{
肥満糖尿病患者における シタグリプチンの効果に及ぼすスタチンの影響
}

\author{
尾上由華 ${ }^{1}$, 高瀬尚武 ${ }^{1}$, 合田俊一 ${ }^{1}$, 米澤圭祐 ${ }^{1}$, 新免 徹 $^{1}$, 塩江真代

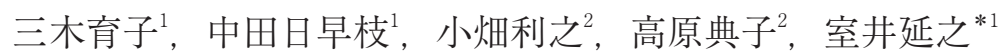 \\ 赤穂市民病院 薬剤部 ${ }^{1}$, 赤穂市民病院 内科 ${ }^{2}$
}

\section{The Influence of Statin Treatment on the Effect of Sitagliptin in Obese Patients with Diabetes}

Yuka Onoue ${ }^{1}$, Naotake Takase ${ }^{1}$, Shunichi Gouda ${ }^{1}$, Keisuke Yonezawa ${ }^{1}$, Toru Shinmen ${ }^{1}$, Masayo Shioe, Ikuko Miki ${ }^{1}$, Hisae Nakata', Toshiyuki Obata ${ }^{2}$, Noriko Takahara ${ }^{2}$ and Nobuyuki Muroi*1

Department of Pharmacy, Ako City Hospital ${ }^{1}$,

Department of Internal Medicine, Ako City Hospital ${ }^{2}$

$$
\left[\begin{array}{l}
\text { Received April 7, } 2015 \\
\text { Accepted September 9, } 2015
\end{array}\right]
$$

This study investigated the influence of treatment with statins on the effect of sitagliptin in obese patients with diabetes.

We studied 52 patients with type 2 obese diabetes who were started on sitagliptin from April 1, 2010 to March 31, 2012. Of these patients, 31 were taking a statin and 21 were not. HbA1c levels were measured at 0 and 3, 6, and 9 months after initiation of sitagliptin.

In obese patients $\left(\mathrm{BMI} \geqq 25 \mathrm{~kg} / \mathrm{m}^{2}\right.$ ), a significant improvement in HbAlc levels was observed only in those taking statins.

Our findings suggest that statins may modify the glucose-lowering effect of sitagliptin in obese patients with type 2 diabetes.

Key words — DPP-4inhibitor, sitagliptin, HMG-CoA inhibitor, obesity, insulin resistance

\section{緒 言}

近年，糖尿病治療薬の進歩は目覚ましく，新た な作用機序を持つ dipeptidyl-peptidase 4（DPP-4） 阻害薬や glucagon-like peptide-1（GLP-1）アナロ グといったインクレチン関連薬が 2010 年より販 売開始となった. インクレチンは，血中グルコー ス依存的にインスリン分泌を促進する特性を持つ が, 生理的なインクレチンは分泌後速やかに DPP-4 による分解を受け失活する。 DPP-4 阻害薬 は, インクレチンを分解する DPP-4に結合し,
内因性の GLP-1 を増大することで効果を発揮す

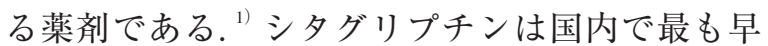
く登場したDPP-4 阻害薬であり, 現在臨床で幅 広く用いられている。

DPP-4 阻害薬が糖尿病薬物治療において重要な 位置を占めるようになるなかで, DPP-4 阻害薬の 治療効果に影響を与える要因についての研究が進 んでいる。日本人におけるシタグリプチン 6 カ月 使用での有効性, 安全性を検討した先行研究にお いて $18 \%$ にタグリプチンの無効・悪化例が認

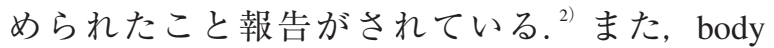

\footnotetext{
*テ678-0232＼cjkstart兵庫県赤穂市中広1090
} 
mass index（BMI）が上昇するほど DPP-4 阻害薬 の $\mathrm{HbA1c}$ 值改善効果が弱くなり BMI 30 以上では DPP-4 阻害薬の効果が認められなかった, ${ }^{3)}$ と肥 満者では DPP-4 阻害薬の治療効果がそしい可能 性が指摘されている.

さらに, DPP-4 阻害薬の治療効果を高める要素 についても研究が行われており，DPP-4 阻害薬によ る HbAlc 值の減少度と血清イコサペント酸（eicosa

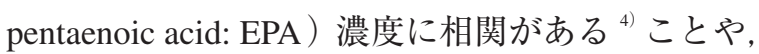
高中性脂肪が脂肪細胞でのインスリン抵抗性を高 め DPP-4 阻害薬の治療効果を低下させ，中性脂 肪低下作用を有する EPA 製剂との併用がより良

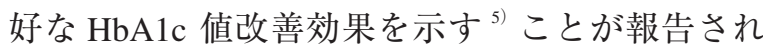
ており，DPP-4 阻害薬の治療効果に対して脂質代 謝が影響している可能性が考えられる。そこで本 研究では, DPP-4 阻害薬の治療効果を減弱すると 報告のある肥満患者において, 高コレステロール 血症治療薬であるスタチン併用が DPP-4 阻害薬 の治療効果へ及ぼす影響について，過去起点コ ホート研究により調査した。

\section{方法}

\section{1. 対象患者および調查項目}

2010 年 4 月 1 日〜 2012 年 3 月 31 日の間に赤穂 市民病院でシタグリプチンによる治療を開始し， 9 カ月以上継続してシタグリプチンによる治療を 行った肥満 2 型糖尿病患者 96 名を対象とした。 本研究では, 日本肥満学会の「肥満症の診断基準 2011」に基づき BMI $\geqq 25$ を肥満とした．そのな かで調查期間中 DPP-4 阻害薬の変更があった症 例，検查值が得られなかった症例，リウマチや化 学療法によってステロイドを使用している症例を 除外し,スタチンを継続して服用していた患者(ス タチン服用群) 31 名抒よび調査期間中スタチンを 服用していない患者（スタチン非服用群）21 名を 抽出した.

患者情報として, 推定糖尿病治療期間, 性別, 年齢，身長，体重，BMI，血清クレアチニン（Scr） 值, eGFR 值, HbA1c 值, LDL-C 值, 並びに併用 されている糖尿病治療薬, 脂質異常症治療薬を力 ルテより調査した。

\section{2. 検討項目}

（1）シタグリプチンの HbA1c 值改善効果に対す るスタチンの影響

シタグリプチン開始月を 0 カ月として, スタチ ン服用群およびスタチン非服用群におけるシタグ リプチン開始 $3,6,9$ 力月後の $\mathrm{HbAlc}$ 值を調査 した.

(2) 9 カ月後の LDL-C 值と HbA1c 值変化量の相関

シタグリプチン開始 9 カ月後の LDL-C 值と開 始時から 9 力月後の $\mathrm{HbA1c}$ 值変化量の相関を調 査した。

\section{3. 統計学的処理}

患者群内の $\mathrm{HbA1c}$ 值についての有意差検定に は wilcoxon test を用い Bonferroni の方法による多 重比較を行った。

群間の有意差検定として, 推定糖尿病治療期間, 年齢, BMI, Scr 值, eGFR 值および開始時 LDL-C 值は Mann-Whitney $U$-test を用いた。 男女比, 併 用薬に関する群間の検定は期待度数が 5 より大き い項目については Chi-square test, 期待度数が 5 以下の項目については Fisher's exact test を用いた. 相関は Spearman's rank correlation coefficient の方 法を用いた，有意水準は $5 \%$ とし，統計解析には J STAT ver 15.0 （佐藤真人，神奈川）を使用した. 本研究は赤穂市民病院の倫理委員会の承認（平 成 25 年 11 月 28 日付）を得て実施した.

\section{結果}

\section{1. 対象患者の患者背景}

今回対象とした肥満 2 型糖尿病患者 52 名のス 夕チン服用群，非服用群に押ける患者背景を表 1 に示す。 スタチン服用群と非服用群で, 推定糖尿 病治療期間, 年齢, 男女比, BMI, Scr 值, eGFR 值に有意な差は認められなかった。 臨床検査值で は開始時 LDL-C 值に有意な差が認められた。併 用されている糖尿病治療薬と脂質異常症治療薬に ついては，スタチン非服用群においてフィブラー 卜系薬剤の併用患者割合が有意に多かった。 
表 1 DPP-4 阻害薬服用の肥満糖尿病患者における患者背景

\begin{tabular}{|c|c|c|c|}
\hline & $\begin{array}{c}\text { スタチン服用群 } \\
n=31\end{array}$ & $\begin{array}{c}\text { スタチン非服用群 } \\
n=21\end{array}$ & $P$ 值 \\
\hline 推定糖尿病治療期間（year） & $9.26 \pm 1.15$ & $7.14 \pm 6.85$ & ${ }^{*} \mathrm{NS}$ \\
\hline 年齢（歳） & $67.70 \pm 1.71$ & $61.83 \pm 2.95$ & ${ }^{*} \mathrm{NS}$ \\
\hline 男 /女（男性の割合） & $14 / 17(45 \%)$ & $12 / 9(57 \%)$ & ${ }^{+} \mathrm{NS}$ \\
\hline BMI $\left(\mathrm{m}^{2} / \mathrm{kg}\right)$ & $27.17 \pm 0.43$ & $27.89 \pm 0.42$ & ${ }^{*} \mathrm{NS}$ \\
\hline $\operatorname{Scr}(\mathrm{mg} / \mathrm{dL})$ & $0.88 \pm 0.07$ & $0.78 \pm 0.04$ & *NS \\
\hline eGFR $\left(\mathrm{mL} / \mathrm{min} / 1.73 \mathrm{~m}^{2}\right)$ & $66.58 \pm 4.12$ & $73.19 \pm 3.44$ & ${ }^{*} \mathrm{NS}$ \\
\hline 開始時 LDL-C（mg/dL） & $95.84 \pm 3.97$ & $118.7 \pm 5.33$ & ${ }^{*} P<0.05$ \\
\hline \multicolumn{4}{|l|}{ 糖尿病治療薬使用患者数 } \\
\hline スルホニル尿素類 & $16(52 \%)$ & $12(57 \%)$ & ${ }^{+} \mathrm{NS}$ \\
\hline ビグアナイド類 & $16(52 \%)$ & $15(71 \%)$ & ${ }^{+} \mathrm{NS}$ \\
\hline 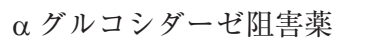 & $7(23 \%)$ & $3(14 \%)$ & ${ }^{++} \mathrm{NS}$ \\
\hline チアゾリジン誘導体 & $4(13 \%)$ & $1(5 \%)$ & ${ }^{++} \mathrm{NS}$ \\
\hline 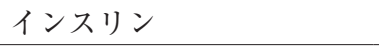 & $8(26 \%)$ & $2(10 \%)$ & ${ }^{++} \mathrm{NS}$ \\
\hline \multicolumn{4}{|l|}{ 脂質異常症治療薬使用患者数 } \\
\hline エゼチミブ & $1(3 \%)$ & $3(14 \%)$ & ${ }^{++} \mathrm{NS}$ \\
\hline フィブラート & $0(0 \%)$ & $4(19 \%)$ & ${ }^{++} P<0.05$ \\
\hline
\end{tabular}

Mean \pm SEM, * Mann-Whitney $U$-test, + Chi-square test, ++ Fisher's exact test.

\section{2. シタグリプチンの $\mathrm{HbA} 1 \mathrm{c}$ 值改善効果に対 するスタチンの影響}

肥満 2 型糖尿病患者 52 名のスタチン服用群, 非服用群におけるシタグリプチン開始 $3 ， 6 ， 9$ カ 月後の $\mathrm{HbA1c}$ 值推移を図 $1 \mathrm{~A}$ に, 開始時から 3,6 , 9 力月後の変化量を $\Delta \mathrm{HbA1c}$ 值推移として図 1B に示す．スタチン服用群 31 名では, シタグリプ チン開始時の $\mathrm{HbAlc}$ 值は $8.14 \pm 0.28 \%$ を示し,
3 カ月後は $7.73 \pm 0.25 \%, 6$ 力月後は $7.67 \pm 0.26 \%$, 9 カ月後は $7.60 \pm 0.26 \%$ とすべての時点で有意な HbA1c 值の減少が認められた。一方, スタチン 非服用群 21 名では, 開始時 $\mathrm{HbA} 1 \mathrm{c}$ 值は $7.92 \pm$ $0.26 \%$ を示し, 3 力月後は $7.15 \pm 0.17 \%$ と有意に 減少していたが，6力月後は $7.24 \pm 0.16 \%, 9$ カ 月後では $7.50 \pm 0.17 \%$ を示し有意な低下は認め られなかった。
(A)

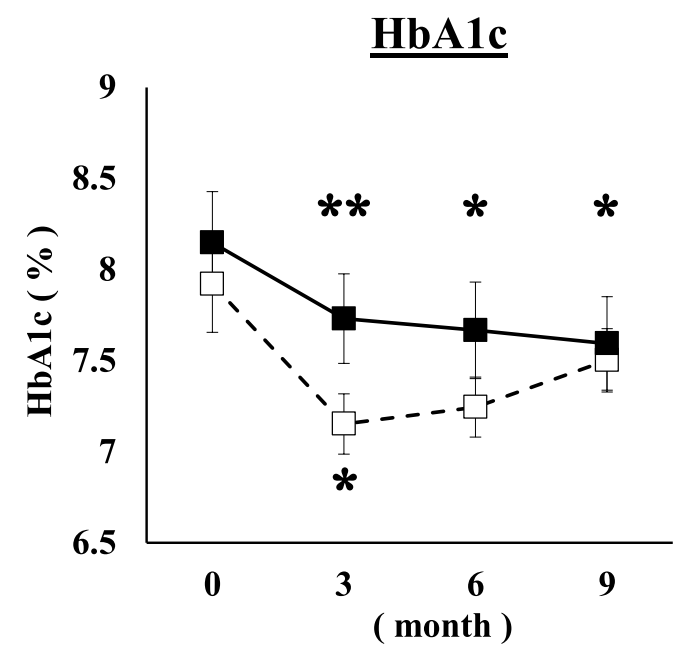

( B )

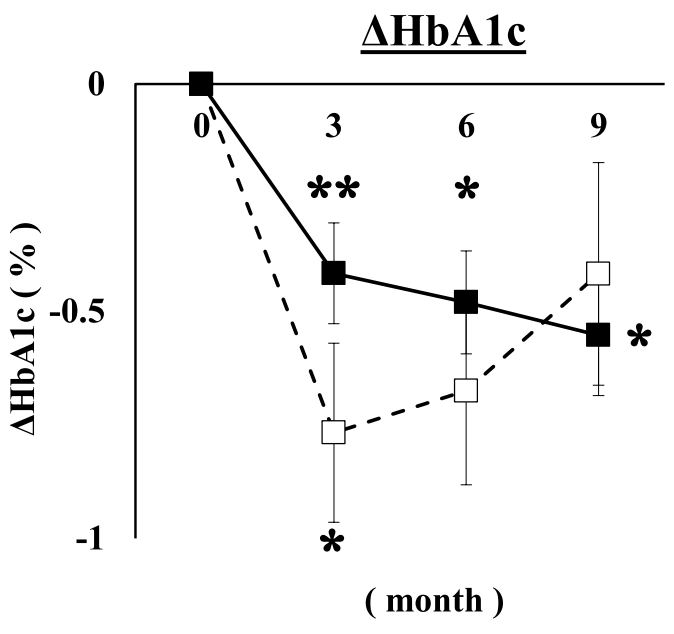

図 1 シタグリプチンの $\mathrm{HbA1c}$ 值改善効果に対するスタチンの影響

-ースタチン服用群 $(\mathrm{n}=31),-\square$-スタチン非服用群 $(\mathrm{n}=21)$. Wilcoxon test with Bonferroni correction; $* * P<0.01$ vs $0, * P<0.05$ vs 0 


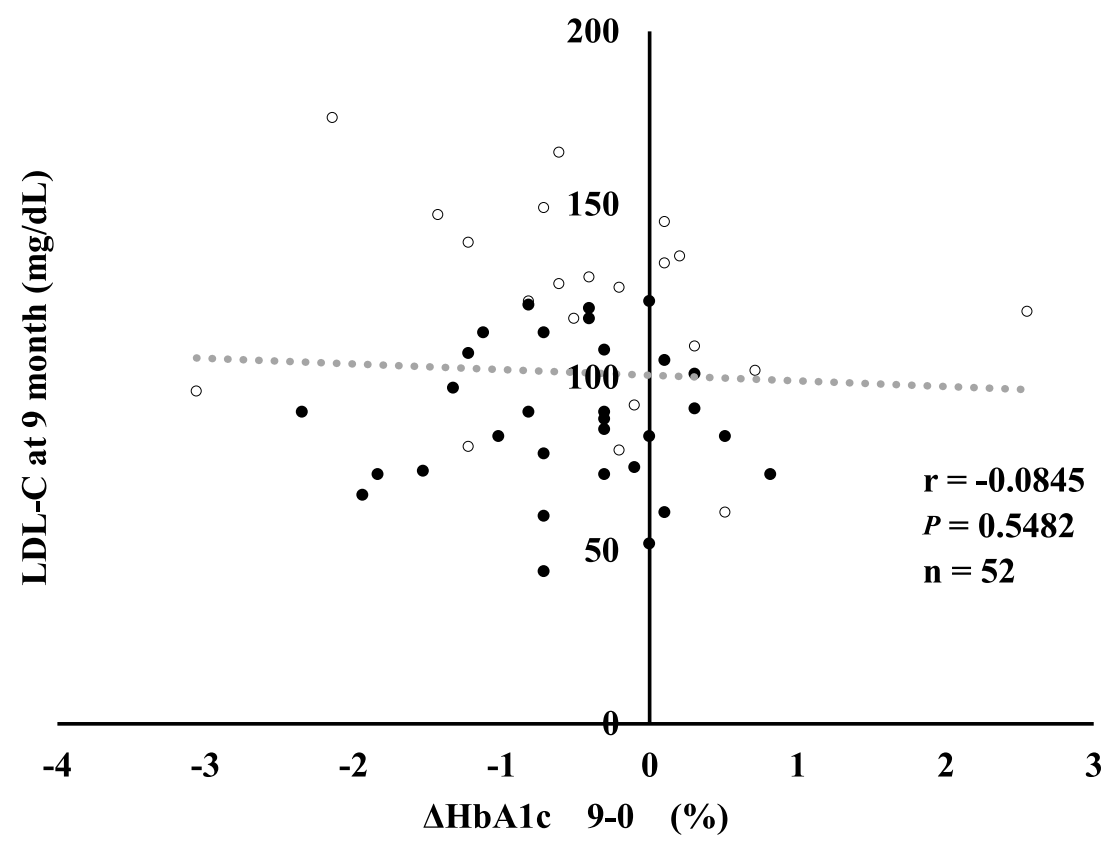

図 2 肥満患者における LDL 值と HbA1c 值変化量の相関

○スタチン服用群 $(n=31)$, ○スタチン非服用群 $(n=21)$. Spearman's rank correlation coefficient

\section{9 カ月後の LDL-C 值と HbA 1c 值変化量の 相関}

肥満 2 型糖尿病患者 52 名における，シタグリ プチン開始 9 カ月後の LDL-C 值と開始時から 9 力 月後の $\mathrm{HbA} 1 \mathrm{c}$ 值変化量の相関を図 2 に示す。 タグリプチン開始 9 カ月後の LDL-C 值と HbAlc 值変化量には有意な相関は認められなかった。

\section{考察}

DPP-4 阻害薬の有効性，安全性に関する評価が 進むなか, DPP-4 阻害薬の治療効果に影響する因 子の検討は糖尿病の治療効果を向上させるうえで 臨床的に有用である。先行研究において, DPP-4 阻害薬の治療効果が肥満で減弱する, ${ }^{3)} \mathrm{EPA}$ が DPP-4 阻害薬の治療効果を向上させる ${ }^{4,5)}$ との報 告があり, DPP-4 阻害薬の治療効果に対して脂質 代謝改善薬の作用が影響している可能性が考えら れるが，DPP-4 阻害薬の効果が減弱する肥満患者 において, 臨床で広く使用されているスタチン併 用の影響については明らかとなっていない. そこ で本研究では, 肥満 2 型糖尿病患者において高コ レステロール治療薬のスタチン併用がシタグリプ
チンによる HbA1c 值改善効果に及ぼす影響につ いて検討した。肥満の定義としては, 日本肥満学 会による「肥満症診断基準 2011」が BMI $\geqq 25$ をもって肥満者としていること, また, 先行研究 で DPP-4 阻害薬の治療効果について検討してい る報告 ${ }^{6}$ についても肥満として $\mathrm{BMI} \geqq 25$ を用い ていることから，本研究においても BMI $\geqq 25$ を カットオフ値とした.

肥満 2 型糖尿病患者におけるシタグリプチンの $\mathrm{HbA1c}$ 值低下作用へのスタチン服用による影響 についての検討の結果, スタチン服用群において はシタグリプチン開始 $3,6,9$ カ月後で $\mathrm{HbA1c}$ 值の減少を認めたが, 非服用群は開始 3 力月後に 有意な低下を認めたものの 6,9 力月後には有意 な低下が見られず， HbA1c 值の上昇傾向を示し た。このことより肥満者において，スタチン非服 用では DPP-4 阻害薬の治療効果の減弱が見られ るが，スタチン服用では DPP-4 阻害薬の治療効 果が持続する可能性が示唆された。

DPP-4 阻害薬は内因性インクレチンの分解を阻 害して薬効を発揮する薬剤であり, インクレチン は膵 $\beta$ 細胞におけるインスリン分泌システムの促 進を行うことで血糖減少に寄与する薬物である. 
一方, 肥満は高脂肪食, 運動不足などの生活習慣 の下で惹起され，インスリン抵抗性の原因となる ことが知られている. ${ }^{7)}$ DPP-4 阻害薬の効果が肥 満患者において減弱する原因として, 肥満による インスリンの作用不足の関連が示唆されている. 健康成人に扔ける研究では, 血清 DPP-4 活性は BMI と正の相関を示すことが報告 ${ }^{8)} さ れ て お り ，$ BMI 高值の肥満者で DPP-4 阻害薬の治療効果が 減弱する理由として, DPP-4 活性の影響も示唆さ れている. また，シタグリプチンの治療効果のリ バウンドは体重の増加や生活習慣のコンプライア

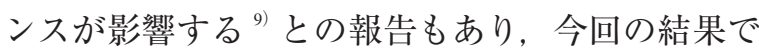
はシタグリプチン，スタチン非服用の $\mathrm{HbAlc}$ 值の 変化（図1）はリバウンド型を示していた。これ らの報告より, 本研究に抢いてスタチン非服用群 でシタグリプチンの作用の減弱が見られた原因と してインスリン抵抗性や DPP-4 活性, 生活コンプ ライアンスなどが関与した可能性が考えられる.

スタチン併用による DPP-4 阻害薬の効果持続 については，これまで報告が行われていない。本 研究ではス夕チン服用群と非服用群の患者背景比 較において, 開始時の LDL-C 值はスタチン服用 群で有意に低い值を示した。 また，スタチン服用 による DPP-4 阻害薬の治療効果と LDL-C 值の関 連について, シタグリプチン開始 9 カ月後の LDL-C 值と開始時から 9 力月後までの HbAlc 值 変化量の相関を調べた結果, LDL-C 值と HbAlc 值の変化量に有意な相関は認められず，スタチン は脂質異常症コントロールとは別の要因によって DPP-4 阻害薬の治療効果を高めている可能性が示 唆された。

スタチンは LDL-C 值低下作用を有しており臨 床では脂質異常症治療薬として多くの患者に使わ れているが，LDL-C 值低下作用以外にも多面的 効果を有し抗酸化作用, 血管内皮細胞の分化増殖 などの作用を持つことが知られており，その $1 つ$ に抗炎症作用がある. ${ }^{10)}$ 肥満がインスリン抵抗性 を引き起こす機序として, 肥満細胞から分泌され るアデイポカインが注目されている. アデイポカ インには TNF- $\alpha$, レジスチン, FFA などインス リン抵抗性惹起性の悪玉サイトカインと, 骨格筋 や肝臟に作用し脂肪酸の燃焼と糖の取り込みを促
進しインスリン抵抗性の改善を行う作用を有する 善玉のアディポカインが知られており, 代表的な 善玉アディポカインであるアデイポネクチンの低 下はインスリン抵抗性に関連するとされる。?

以上のことから, 本研究においてスタチン非服 用群で DPP-4 阻害薬の治療効果が減弱したのに 対し，スタチン服用群ではシタグリプチンによる HbA1c 值低下作用が持続した一因としては，イ ンスリン抵抗性悪化の背景を持つ肥満患者に抢け る DPP-4 阻害薬の治療効果減弱に対して, 抗炎 症作用を持つスタチンがインスリン抵抗性改善を 介して DPP-4 阻害薬の治療効果持続に作用した 可能性が考えられる.

一方, スタチンにより糖尿病発症リスク増加に ついての報告がされており， JUPITER studyのサ ブ解析よりロスバスタチンの使用でプラセボに比 ベ 2 型糖尿病発症リスクが $27 \%$ 高い ${ }^{11)}$ という報 告や，高用量のアトルバスタチン投与により， 2 型糖尿病の新規発症リスクがプラセボと比較して わずかに上昇した報告がある. ${ }^{12)}$ アトルバスタチ ン, ロスバスタチン, シンバスタチンでは有意に 糖尿病発症リスクを上昇させたが，プラバスタチ ンは糖尿病発症リスクとの関連が少ないという報 告 ${ }^{13)}$ もあり, ス夕チンの種類によって糖尿病発 症リスクへの影響が異なる可能性が示唆されてい る.また, DPP-4 阻害薬の効果に影響する因子と してアディポサイトカインとスタチンについての 研究も行われている. 冠動脈疾患を有する患者で の臨床試験においては, ピタバスタチンでは有意 な血清アデイポネクチン值の増加を認めたがアト ルバスタチンにおいては有意な変化が認められな かった. ${ }^{14)}$ また， ロスバス夕チン投与患者におい て血清アディポネクチン值が増加傾向であったと いう報告 ${ }^{15)}$ もある。 今回の検討でのスタチン服 用群 31 名に打けるスタチンの内訳は, ロスバス タチン 12 名, アトルバスタチン 11 名, ピタバ スタチン 3 名, その他のスタチン 5 名であり, スタチンの種類によって DPP-4 阻害薬の治療効 果へ及ぼす影響にも違いが生じる可能性がある。

本研究は肥満 2 型糖尿病患者に打いてスタチン の併用が DPP-4 阻害薬の治療効果を高める可能 性を示唆した。 今後症例数を増加し, スタチンの 
種類別による DPP-4 阻害薬への影響について検 討する必要があると考える。

\section{利益相反}

開示すべき利益相反はない.

\section{引用文献}

1）李 相翔, 長嶋理晴, 平野 勉, 渡部环也, 糖尿 病治療を変える新たな糖尿病薬インクレチン, 昭和医学会雑誌, 2010, 70, 34-44.

2) Tajiri Y, Tsuruta M, Ohki T, Kato T, Sasaki Y, Tanaka K, Kono S, Tojikubo M, Yamada K, Long-term efficacy of sitagliptin for the treatment of type 2 diabetic patients in Japan, Endocr J, 2012, 59, 197-204.

3) Kim YG, Hahn S, Oh TJ, Kwak SH, Park KS, Cho $\mathrm{YM}$, Differences in the glucose-lowering efficacy of dipeptidyl peptidase-4 inhibitors between Asians and non-Asians: a systematic review and meta-analysis, Diabetologia, 2013, 56, 696-708.

4) Iwasaki M, Hoshian F, Tsuji T, Hirose N, Matsumoto T, Kitatani N, Sugawara K, Usui R, Kuwata H, Sugizaki K, Kitamoto Y, Fujiwara S, Watanabe K, Hyo T, Kurose T, Seino Y, Yabe D, Predicting efficacy of dipeptidyl peptidase-4 inhibitors in patients with type 2 diabetes: Association of glycated hemoglobin reduction with serum eicosapentaenoic acid and docosahexaenoic acid levels, Journal of Diabetes Investigation, 2012, 3, 464-467.

5）藤本 綾, 谷後友絵, 池本雅章, 佐々木雄啓, 木村 孝司, 松山彰子, 斉藤 茜, 佐和章弘, 三宅勝志, シタグリプチン服薬患者の HbA1cの推移と治療 成績に影響を与える重要因子の検討, 日本病院 薬剤師会雑誌, 2012, 48, 1221-1225.

6）松久宗英, 河盛隆造, 浅野昭道, 綾目秀夫, 家光 浩太郎, 池淵元祥, 石丸安明, 伊藤景樹, 大河内 昌弘, 大橋 博, 岡田洋右, 金丸良文, 川知雅典, 菅野一男, 岸谷 讓, 栗林伸一, 迫康博, 澤山 泰典, 周東 寛, 陣内秀昭, 杉浦 立, 杉本正毅, 高橋郁夫, 竹川 潔, 武田浩, 田中誠一, 田中 博志, 中井一彰, 永井幸広, 中田邦也, 永田就三, 西頭知宏, 二宮 裕, 日吉 徹, 福田正博, 福元 良英, 水林竜一, 三谷裕昭, 柳澤克之, 山本繁樹, 李 源台, 診療の実際から DPP-4阻害薬ビル ダグリプチンの臨床評価 一市販後使用経験の
集積デー夕分析一, 新薬と臨牀, 2011, 60, 19601978.

7）門脇 孝, 山内敏正, 窪田直人, “アディポネク チンと糖尿病 ・心血管病の分子メカニズム”第 128回日本医学会シンポジゥム記録集, 2004, pp 34-45.

8) Kirino Y, Sei M, Kawazoe K, Minakuchi K, Sato Y, Plasma dipeptidyl peptidase 4 activity correlates with body mass index and the plasma adiponectin concentration in healthy young people, Endocr $J$, 2012, 59, 949-953.

9) Kanamori A, Matsuba I, Factors associated with reduced efficacy of sitagliptin therapy: analysis of 93 patients with type 2 diabetes treated for 1.5 years or longer, J Clin Med Res, 2013, 5, 217-221.

10) Tandon Vishal, Bano G, Khajuria V, Parihar A, Gupta $\mathrm{S}$, Pleiotropic effects of statins, Indian J Pharmacol, 2005, 37, 77-85.

11) Ridker PM, Danielson E, Fonseca FA, Genest J, Gotto AM Jr, Kastelein JJ, Koenig W, Libby P, Lorenzatti AJ, MacFadyen JG, Nordestgaard BG, Shepherd J, Willerson JT, Glynn RJ, JUPITER Study Group, Rosuvastatin to prevent vascular events in men and women with elevated C-reactive protein, N Engl J Med, 2008, 359, 2195-2207.

12) Waters DD, Ho JE, DeMicco DA, Breazna A, Arsenault BJ, Wun CC, Kastelein JJ, Colhoun H, Barter P, Predictors of new-onset diabetes in patients treated with atorvastatin: results from 3 large randomized clinical trials, J Am Coll Cardiol, 2011, 57, 1535-1545.

13) Carter AA, Gomes T, Camacho $X$, Juurlink DN, Shah BR, Mamdani MM, Risk of incident diabetes among patients treated with statins: population based study, BMJ, 2013, 346, f2610. doi: 10.1136/ bmj.f2610.

14) Kurogi K, Sugiyama S, Sakamoto K, Tayama S, Nakamura S, Biwa T, Matsui K, Ogawa H, COMPACT-CAD Investigators, Comparison of pitavastatin with atorvastatin in increasing HDLcholesterol and adiponectin in patients with dyslipidemia and coronary artery disease: the COMPACTCAD study, J Cardiol, 2013, 62, 87-94.

15）広瀬 寛, 神田武志, 河邊博史, 齊藤郁夫, ロスバ スタチン $5 \mathrm{mg}$ /日投与時の各種代謝指標に及ぼす 影響, 慶應保健研究, 2014, 32, 043-047. 